\title{
Women Who "Spoke for Themselves"
}

The role and special contributions of women in the development of academic and research librarianship in the United States are shown through the careers of six major librarians: Katharine Sharp, Isadore Gilbert Mudge, Margaret Mann, Adelaide Hasse, Flora Belle Ludington, and Genevieve Walton.

T HE ROLE OF WOMEN in librarianship, and especially in academic and research libraries, has been characterized as one that dominated in physical numbers but did little to provide the leadership essential to a profession struggling to define and justify its own existence. Unfortunately, such a quick assessment does not point out the special significance of those unique women who did provide that leadership while overcoming long-standing and oppressive social traditions, which not only circumscribed their opportunities but also buried their contributions.

Even in 1976, analyses of those who rose to "prominent posts" note a Windsor, but not a Katharine Sharp, a Williamson, but not an Isadore Mudge; cite as notable contributors to the library literature a Billings, but not an Adelaide Hasse, a Bishop but not a Margaret Mann; or find reason to mention a Charles Smith, but not a Flora Belle Ludington or a Genevieve Walton. ${ }^{1}$

Yet the women were there and, as Holley notes, while there were "stories of women having asked 'Papa' Poole, Lloyd Smith or some other male librarian to speak for them in the deliberations at early conferences, they quickly learned to speak for themselves." 2 In that speaking and in their doing lie many biographical studies; the following paragraphs address only six of those "library ladies" and their impact on the academic and research libraries of the twentieth century.

The major period of expansion of

Laurel A. Grotzinger is professor, School of Librarianship, Western Michigan University, Kalamazoo. academic and research libraries in the United States dates from the 1870 s and 1880 s. By that time, the foundations of the system of postsecondary education were well established, and the basic variationsthe colonial college, technical institutes, coeducational institutions, land-grant and other state universities-were easily distinguished. Not so clear, however, was the office of the librarian and the responsibilities of that office in terms of building an educational resource. As McElderry succinctly states, academic libraries, regardless of institutional "type," were often "a miscellaneous assortment of books, primarily gifts, few in number, poorly housed, and scarcely used." 3

At the same time, major public research collections, such as the ones in Los Angeles, Pittsburgh, and New York, were growing rapidly but had yet to be adequately housed, organized, and opened to the public with the full range of services that are commonplace to today's user. Although a number of women, were involved in or closely identified with the development of academic and research libraries and/or the provision of special services, one of the first was Katharine Lucinda Sharp.

\section{KATHARINE SHARP (1865-1914)}

Katharine Sharp was associated with two key aspects of library history in the U.S.: education for librarianship and the promotion of a strong, accessible collection. Her direction of the first library school in the Midwest, at the Armour Institute of Technology in Chicago, from 1893 to 1897 , and the continuation of that program at the 
University of Illinois, from 1897 to 1907 , gave impetus to the acceptance of formal library education as a basic component of preparation for professional work. Graduates of the Illinois program found positions in libraries and library schools throughout the country. As Dewey did before her, Sharp and her faculty colleagues imbued the majority of their students with a sense of the dramatic future of librarianship; those graduates, in turn, became influential advocates of the role of libraries and library service, which Sharp, herself, exemplified.

Katharine Sharp probably would be notable if she had done nothing but build a strong library school, but, in addition, she was instrumental in collecting and organizing the nucleus of the vast research library that currently exists at the University of Illinois. Illinois, one of the first of the landgrant universities, had a library when Sharp arrived in 1897. However, no previous librarian had the foresight or knowledge to take the odds and ends of materials that had been acquired until that time and make them accessible while encouraging the expansion of the collection. Yenawine, in his study on "The Influence of Scholars on Research Library Development at the University of Illinois," documents her ambitious undertaking.

Guided by library statutes and assisted by a Faculty Library Committee, Miss Sharp [by 1900] had consolidated the Library's resources in the Library Building, had departmentalized the work and trained a staff, had systematized procedures for book selection and acquisition, organized reference services, and had recataloged a large part of the collection. ${ }^{4}$

Such an accomplishment was not due to chance. All of her preparation had emphasized principles of "library economy" and a logical approach to collection development. In fact, that preparation and her own unique personality made her one of the widely recognized leaders of that period.

Sharp, in contrast to a number of other pioneers of that age, was a completely midwestern product. Born, on May 21, 1865, in Elgin, Illinois, she was fortunate in her attendance at the Elgin Academy, a progressively liberal school. She completed her studies at the age of fifteen and a year later was enrolled in Northwestern University. In

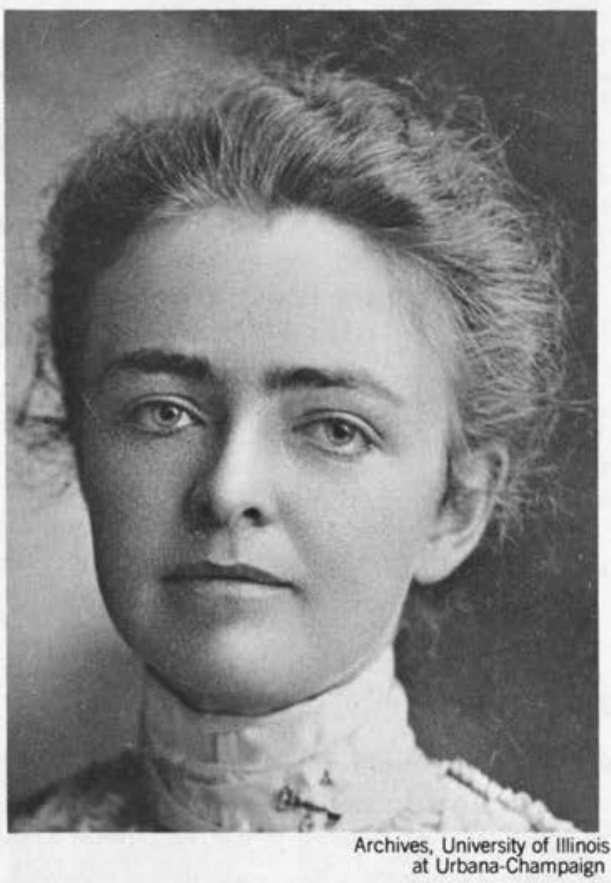

Katharine Sharp

1885 she received the degree of Bachelor of Philosophy with Honors in General, Latin, and Special Scholarship. Ultimately she also earned a B.L.S. in the New York State Library School, a master's degree from both Northwestern and the New York State Library School, and, after her retirement, was given an honorary degree by the University of Illinois. There was little doubt that she was a brilliant student and, more important, was able to apply what she learned in a variety of situations.

Her first position involved teaching at the Elgin Academy, but this proved unsatisfactory, and she became an assistant librarian in the public library of Oak Park, Illinois, in 1888. Shortly after she began her second year of library work, she applied for admission to the infant library school that had just been transferred to Albany, New York, after Dewey's lost battle with the trustees of Columbia. Sharp's decision to apply to that school was a gamble, since she had to resign her position, move to the east, and study for two years under a man who was an extraordinary leader but also one of the most 
controversial individuals in the country. It was, at least with respect to her future, a fortuitous choice, since Dewey was the professional contact who provided access to the "old boy network" of that period.

During her years of study at Albany, Sharp gained further experience cataloging and organizing small collections in Illinois and Ohio. Her record at the library school was excellent, and she was, as Dewey noted, "easily first" 5 in a class that also included Edwin Hatfield Anderson, Mary Esther Robbins, and William Reed Eastman. Dewey's identification of her as "the best man in America"6 to direct the library and library school at the new vocational institute in Chicago was the only recommendation necessary to place her in a position from which she could build a reputable educational program and, four years later, begin her consolidation and creation of the foundations of the research library at the University of Illinois.

The years of Katharine Sharp's career were relatively brief in number. She opened the Armour school in the fall of 1893 and some fourteen years later, in 1907, resigned from her position as head librarian, director of the library school, and professor of library economy at the University of Illinois. Although it was anticipated that she would eventually return to her library career, her delight in her position as vicepresident of the Lake Placid Club and her tragically early death in 1914 at the age of forty-nine left no opportunity for that future involvement. Regardless, less than two decades of service to the profession produced accomplishments that are neither insignificant nor transitory. Her outstanding work in establishing the Illinois library school and formalizing the curriculum leading to a degree in library science was probably the factor most important in assuring the continuation of university-associated education for librarianship in the Midwest.

Her lifelong dedication to the future of library services in the state of Illinois led to the formation of the state library association and brought an extension of library service into many communities-through her founding and direction of a bureau of information and through the library courses she and her staff taught, outside the Chicago and
Champaign/Urbana communities. Although Sharp was unable to bring about the creation of a state library commission, she left a strong association, interested citizens, and numerous well-prepared librarians who were dedicated to the same ideals of service and library expansion to which she had devoted her professional life. She was an active and contributing member of other professional associations including ALA, where she served ten years on the council and two terms as vice-president.

Katharine Sharp's life, however, may not be best assessed in terms of the events just chronicled. In many respects, her most significant role came in the influence she had on others of that period-especially on the young women with whom she came in contact in those formative years of library work, who, in turn, brought their forces to bear on the library community. One such individual, a member of Sharp's staff at the University of Illinois, was Isadore Gilbert Mudge.

\section{ISADORE GILBERT MUDGE (1875-1957)}

In McElderry's analysis of the evolution of the academic library, five categories are identified, which, he suggests, represent chronological trends in service to readers. His first and second periods are described as ones concerned, as was Katharine Sharp at the University of Illinois, with the "accumulation of materials" and the "organization of resources." 7 The third facet of library growth, the "personal assistance to readers," was also of singular interest to Sharp, who brought to Illinois, in 1900 , a woman who was to earn a special place in the history of library reference services.

Isadore Gilbert Mudge, as her biographer, John Waddell, notes,

was born March 14, 1875, the oldest child of Alfred and Mary Ten Brook Mudge. Both her parents had been raised to respect the importance of higher education and to appreciate the satisfactions of professional achievement. Her maternal grandfather, Andrew Ten Brook, was a minister, a professor, and for many years the librarian of the University of Michigan; her paternal step-grandfather, Charles K. Adams, was the president of Cornell and later of the University of Wisconsin and was instrumental in the building of fine new libraries at both places.... It was a family of achievers. ${ }^{8}$ 
Mudge, just ten years younger than Katharine Sharp, also reached college age at a time when she was able to attend an institution of higher education other than those that catered solely to females; she could think seriously about a career other than marriage. Given her background and fine educational preparation at the Adelphi Academy in Brooklyn, she found little difficulty in matriculating at Cornell University in 1893.

She was an excellent student who was one of three elected to Phi Beta Kappa in the junior year but, more important, was given the opportunity to study under a number of superlative professors and to make use of an excellent library: "Probably nowhere else in the world could a young woman of her age have had access to such a strong collection, and it is obvious from the nature of the courses she took and the high grades she made that she must have spent countless hours using its resources." 9

Mudge enrolled in the New York State Library School in 1898 and graduated in 1900 having earned the B.L.S. degreeagain with an outstanding record including a " 100 " in reference. Not surprisingly, she was recommended to the "demanding" Miss Sharp of Illinois, who wanted only the best for her library staff and her school.

Katharine Sharp had recognized the need for specialized reference personnel early in her career. When the library school was transferred to the university, Sharp fought to employ highly qualified individuals to carry the responsibility of both giving and teaching reference service. As she wrote in 1901 , "without a reference librarian to devote her entire time to the work, a university library must be restricted in one of the most important phases of its work."10

When Mudge arrived in the summer of 1900 , she had a tremendous task to handle, with what was then a paltry collection compared to those resources available at Cornell or some of the other universities of the East. However, even in these early years, she had a certain sense of the role of an effective reference librarian. Her statement of the function of the reference department, in 1902 , noted that "an all-round, wellbalanced collection of the best reference books in English" should be built; that it

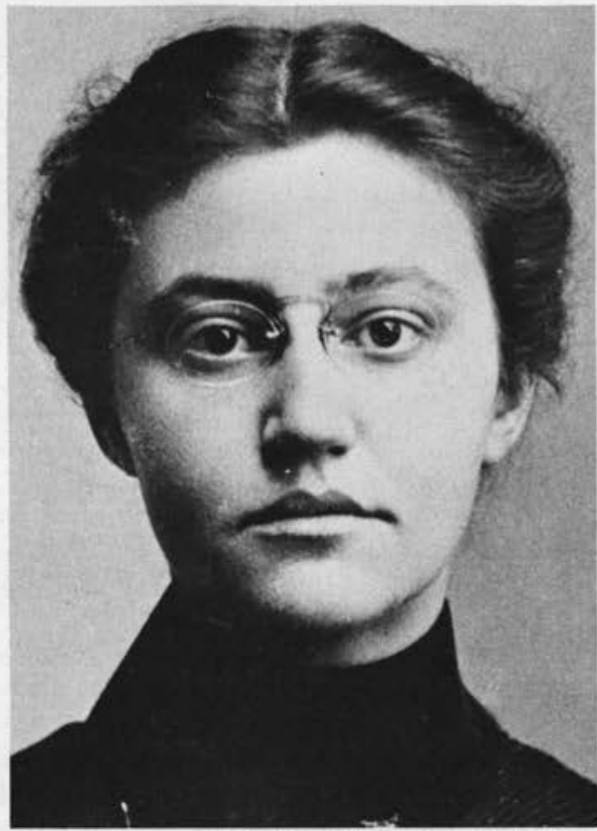

Columbiana Collection, Columbia University

Isadore Gilbert Mudge

should be located "where it can be most easily and conveniently consulted"; and that the librarian should "give personal help in the use of the library whenever possible and in giving such help to endeavor always to help the student to independent and intelligent use of the library resource." 11

During the same years that Mudge gained valuable first experiences at the reference desk, she also taught in the library school. Although her teaching methods were not comparable to those of later years, given the nature of the Illinois collection and the relatively elementary nature of its curriculum, the involvement and her contact with Sharp, Margaret Mann, Minnie Sears, and others provided the basis for future friendships as well as for professional development. Sears became a special friend and collaborated closely with Mudge in both her library and literary work of the next several decades.

By 1903 Mudge was ready to return to her beloved east coast. An opportunity for advancement came in the acceptance of the position of head librarian at Bryn Mawr. It 
is likely that Dewey was again involved, since graduates of the Albany school had been earlier librarians at that college; Sharp also recommended her and wished her success.

Sears went with Mudge to Bryn Mawr as her cataloger, and both left the college in 1907 to spend a year traveling in Europe. After the year there, during which she and Sears compiled A Thackeray Dictionary, ${ }^{12}$ she spent the next three years in a variety of activities. From 1909 to 1911 she worked with William Dawson Johnston, librarian at Columbia, in compiling a directory of special collections in American libraries. ${ }^{13}$ In 1910 she was employed at Simmons College library school where she was recognized for her teaching ability.

In the same period she contributed the first of numerous reviews to Library Journal, and, possibly most important, Mudge took over Alice Bertha Kroeger's Guide to the Study and Use of Reference Books ${ }^{14}$ and published supplements in the Library Journal. In 1917 Mudge edited her own first full edition, the third of the Guide; it became the undisputed leader among reference tools of that type. Mudge eventually edited four editions-1917, 1923, 1929, and 1936-before her successor, Constance Winchell, took on the job. As Winchell later wrote

Miss Mudge became the outstanding authority on reference books, and her Guide has been known and consulted in libraries throughout the world ..... Her thorough familiarity with reference books and reference techniques, her clear thinking, her wide knowledge and remarkable memory, and her deep interest in the subject and in the student or research worker, all combined to impress her influence on succeeding generations of students, colleagues-all who used her book. ${ }^{15}$

Closely tied to her ability to earn this reputation and produce the Guide was Mudge's career at Columbia University. Although Simmons College desired to keep her as an instructor, Mudge claimed that she had "for some reason set my mind on wanting Columbia from the days that I was at Cornell." 16 Her interest in the institution eventually led her to accept a position in gifts and exchanges, which began February 6,1911 . A few months later, on June 15, she was appointed reference librarian, a position she held until her retirement thirty years later, in 1941.

In 1927 she added the second element to her distinguished career when she was made an associate professor of bibliography of the recently opened School of Library Service, which had grown out of a merger of the New York State Library School at Albany and the library school that operated within the structure of the New York Public Library. The combination of Mudge's dual role as reference librarian and instructor plus the superb facilities of the university library provided the environment that shaped the future of much of reference work in America. During the years of her tenure she focused on the centralization and expansion of the collection, the selection and education of staff, and, key to it all, the definition of professional service to the scholar.

Word of mouth reputation of Mudge's services spread, so that in a relatively short time she was able to demonstrate factually to the library administration something of the achievements and the growth of her department ..... Staff and collection were important in furthering the development of the reference department, but the real key to success was, of course, Mudge's almost superhuman skill in answering questions of great variety in subject and in level, and in training her carefully chosen assistants to learn to do almost as well. In later years she phrased a glib prescription for success in reference work, which she called the three M's-material, mind, and method. ${ }^{17}$

A glib prescription or not, Mudge's three "M's" became the basis for her resourceful and influential classes in the library school-classes that in turn produced future instructors who based their methods on her work. As Winchell later wrote, "probably no other one person has contributed so much to raising the standards of reference collections and reference service in the libraries of this and other countries." 18

That rare spirit was eventually recognized by the American Library Association, which established in 1958 the Isadore Gilbert Mudge Citation to be given to others who had, in the image of Mudge, made a "distinguished contribution to reference librarianship." 


\section{MARGARET MANN (1873-1960)}

"Her chief service to librarianship," wrote Bishop in 1938 when Margaret Mann was preparing for retirement after a career that had spanned four decades, “. . . is the training she has given her students in earlier and in later years. She has shown them that cataloging is work of absorbing interest and never-ending variety; that classification of books calls for a happy combination of scholarship and practical sense; that both are fundamental processes in the conduct of any library. ${ }^{19}$ William Warner Bishop, perhaps, overemphasized the final years of Mann's professional life, when she was the best known instructor in cataloging and classification in America.

Mann had spent at least as many years in cataloging materials as she spent in teaching, and her contributions in this area, if not unmatched in her time, surely identified her as an expert in the field. At the same time, her climactic years in the library school at the University of Michigan did focus her ideas about the organization of resources in such a way as to produce her classic text, Introduction to Cataloging and the Classification of Books, ${ }^{20}$ a work described by Lehnus, in his analysis of "milestones in cataloging" as "not only the most cited manual, but also one cited as much as others which have had more recent revised editions .... . Even though there are more recent texts than that of Mann, hers has proven its superiority through its quality." 21

Margaret Mann's entrance to librarianship did not build on the educational and cultural strengths seen in the background of both Sharp and Mudge. She was born on April 9, 1873, in Cedar Rapids, Iowa, and her early years were circumscribed by the rural community in which she was raised and in which her father worked as a dry goods merchant. After Amasa Mann moved his family to a suburb of Chicago in 1890 , Margaret was able in 1893 to obtain her secondary diploma from Englewood High School. She was then twenty years old.

As with many young women of that period, her options for employment were limited, but she was able to benefit from the circumstances that brought, in the year of her graduation, the opening of the Armour

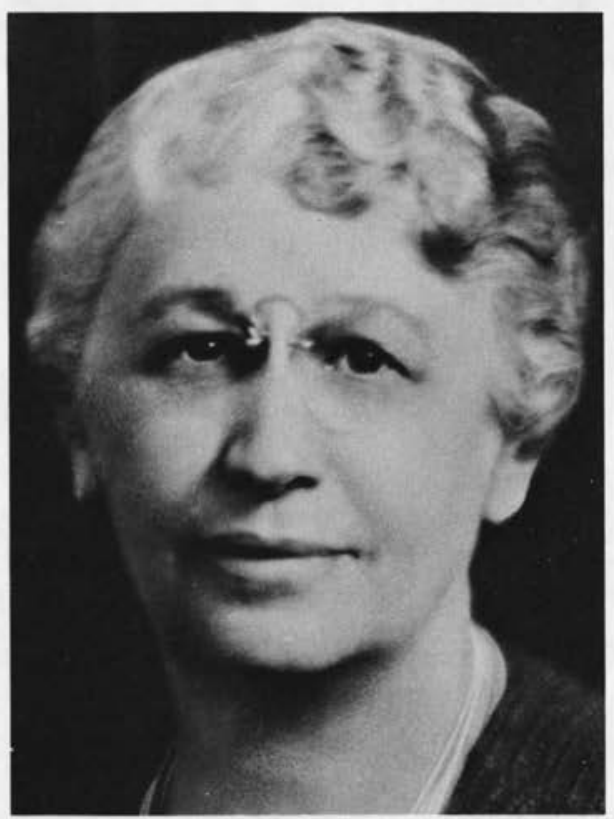

University of Michigan

Margaret Mann

Institute library school. She passed the application test for the Armour Institute library course with ease and was one of twelve young women who began study on September 14, 1893, in the first class of the Department of Library Science. From that day on, Margaret Mann's future in the profession was assured-both by her own abilities and her contacts with Katharine Sharp and, through her, Dewey.

Records indicate that she was an all " $\mathrm{A}$ " student who was so expert that Katharine Sharp hired her, in 1894, after only a year of study under limited conditions, to catalog in the Armour library and, also, while taking a second year of work, in 1895-96, to serve as an instructor in the beginning classes.

Mann was especially attracted to the area of cataloging and classification; it not only appealed to her own well-organized habits and intellectual interests, but it was, at the time, the only area of librarianship that was codified in any systematic way-there was something upon which to base decisions. Moreover, she was an advocate of the basic 
assumption that the catalog was the key to effective library use and that its value was based on the skill of the cataloger. She not only practiced this belief, as is evident in her innovative and user-oriented catalog modifications found at the Carnegie Library in Pittsburgh and the Engineering Societies Library in New York, but she made it the emphasis of her courses in which she stressed the discipline of the subject.

[The study of cataloging] develops an exact way of thinking and doing, and the student comes to realize through such a course the importance of system, accuracy and order. $\mathrm{He}$ comes to accept the fact that, no matter how much knowledge one acquires in handling books, unless this knowledge can be satisfactorily passed on to others, the library is not fulfilling its purpose. ${ }^{22}$

When the Armour Institute library school was transferred to the University of Illinois in 1897, there was never any doubt that Mann would make the move with Sharp. A close and special friendship had developed between the instructor and student. During the period at Illinois, Mann did much to support the massive changes that Sharp had to bring about in order to get the library and library school operating in an efficient manner.

Prior to Sharp's arrival, there had never been a consistent policy of cataloging and classification so that many of the resources needed, at the very least, to be accessioned, shelflisted, and prepared for the shelf; other material needed major reorganization. The only help came from the library school students who had to be closely supervised, but, by the end of the first year, the annual report could state that the library had its material "arranged for easy reference, with its records all systematized." 23

By 1899 Mann was serving both as assistant librarian and senior instructor as well as personally handling all government documents, college catalogs, and other miscellaneous resources. When Edwin H. Anderson, then librarian of the Carnegie Library at Pittsburgh, offered her the position as head of the Cataloging Department in 1902, she could not refuse and, from 1903 to 1919 , was instrumental in directing the development of the catalog at that institution.

The Carnegie Library of Pittsburgh enjoys a peculiar distinction among American libraries-a distinction which it owes directly to Margaret Mann. It is the sole American library of size and importance which has published a classified and annotated catalog on a large scale .... The execution of this huge and formidable task was carried out under Miss Mann's close and continuous supervision. ${ }^{24}$

Although her long years of work at Pittsburgh began to suggest that she might eventually retire in that community, Mann readily accepted a totally new challenge in 1919 when Harrison Craver asked her to bring order to the assorted libraries of the United Engineering Societies in New York City. This work in a special library not only added to her cataloging experience but brought to a forefront her ideas about adapting a collection to the needs of the user and producing a usable catalog. As she wrote several years later,

... libraries are formidable places at best . . . People who use the library are immediately aware of their shortcomings and very few like to expose the fact that they do not know the answer to the question they want to look up .... With this situation it is much better for the shy reader (and there are many of them) to be able to go to the catalog and look up his own information. He will be more likely to come again if he can help himself. ${ }^{25}$

In addition, she was quick to utilize the idea that a classed catalog worked more effectively than a dictionary catalog when used with certain subjects-so the Societies' library had a special classed catalog that gave, she noted, "a logical arrangement of titles to supplement the illogical dictionary arrangement." 26

After five years, the collection of the Engineering Societies was largely recataloged and well-organized. It was then that Mann turned her attention to a different and even greater challenge-teaching cataloging and classification in Paris at the Ecole des Bibliothécaires. She taught there for only two years, 1924-26, and although she might have stayed longer, family concerns, several teaching offers, and an agreement to write the ALA textbook on cataloging enticed her to return.

Bishop persuaded her to come to his newly formed library school at the University of Michigan; it was Margaret Mann's last professional home. The final twelve 
years of her active career, 1926-38, were a fitting capstone as she was internationally recognized as an exceptional, talented teacher whose textbook became a classic almost as soon as it was published.

ADELAIDE R. HASSE (1868-1953)

In 1897, an issue of the San Francisco Call ran a two-column illustration of Adelaide R. Hasse and headed it with the phrase, "Famed for her Library Knowledge." As the information under the picture noted, Hasse had formerly been employed by the Los Angeles Public Library and had later "distinguished herself" in the Bureau of Public Documents in Washington. Furthermore, the notice went on, "no woman in the country has a more thorough knowledge of the public documents of the United States than has Miss Hasse. So complete is her information in that line that the head of the bureau has often referred to her as the living index.' "27

The occasion that had caused this glowing commentary to be published was Hasse's appointment as head of the documents department in the Astor Library, which had just been consolidated with the Lenox Library and the Tilden trust to form the New York Public Library. Within a few years, the documents collection "became, the $\mathrm{Li}$ brary Journal observed, 'so completely equipped and so well organized as to form a model of its kind. ... Miss Hasse and her staff produced valuable bibliographies and checklists [and] in $1911 \ldots$ they provide[d] service directly to the public." 28

Adelaide Hasse, as was true of Sharp, Mudge, and Mann, brought her own unique personality and background into focus when she became a librarian. Born September 13, 1868 , in Milwaukee, Wisconsin, Hasse grew up in a family in which her father, a successful surgeon and renowned botanical researcher, gave his children many opportunities to study with private tutors and to share in his own literary interests. Dr. Hasse moved his practice on several occasions, and Adelaide also came to enjoy different environments and to delight in travel.

Adelaide's penchant for what she called "collecting," which originally referred to her enthusiasm for reading and discovering in-

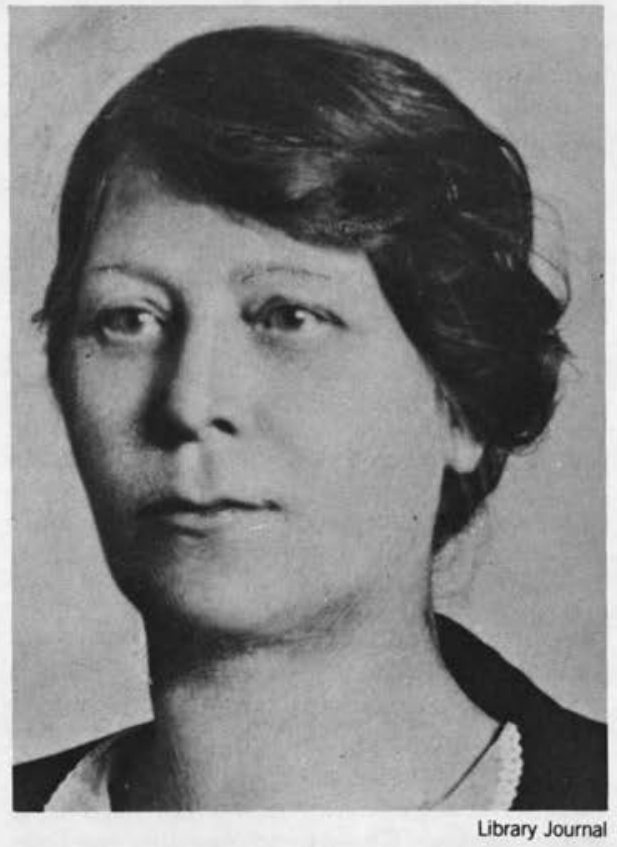

Adelaide Hasse

formation of all kinds, quite logically brought her to a place where collecting was keen-the Los Angeles Public Library. There, in 1889, Hasse became the library assistant to Tessa L. Kelso and took the first steps on her remarkable career path. Years later Hasse noted:

... collecting is great fun. Every employer I have had has been a collector. My first employer was a woman, and it was she who gave point and direction to my natural bent towards collecting. She herself was a remarkable collector of experience. Having had but little library experience herself, she was able, by her ability as a collector of the experience of others, to avail herself thereof and, on the strength of it, to build up one of the livest, most progressive libraries I have known ... [She] aroused my interest in the possibilities of specializing in government documents. She was so sympathetic in her efforts that, almost without being aware of having done so, somehow I had organized the collection of documents, not inconsiderable, in the Los Angeles Public Library, devised a classification for them, and had begun a checklist of them. ${ }^{29}$

From that checklist came the first of nearly two dozen bibliographies that were 
published during the sixty years of Hasse's career-publications that were instrumental in identifying and organizing state, federal, and foreign documents on a variety of topics including, among others, public archives of the thirteen original states, demolitionblighted areas, the trade paper press, finance, Department of Agriculture publications, foreign affairs, and her invaluable Index of Economic Material in Documents of the States of the United States, ${ }^{30}$ a monumental reference resource, which was "in itself a life work for any less industrious and persistent person." ${ }^{31}$ Moreover, from 1894 to 1939 , there are more than fifty articles by Hasse, published in a variety of library and nonlibrary sources, that perceptively define an active and competent library institution as well as chastise an often inactive and incompetent library staff.

Hasse's work in the Los Angeles library was singular enough to bring her to the attention of individuals who had major difficulties in document organization-the U.S. government. The first section of her checklist of public documents, which dealt with agriculture, brought a request from that department for its publication. ${ }^{\mathbf{3 2}}$ Shortly thereafter, knowledge of Hasse's skill in this area was such that, in 1895 , she was offered the position of librarian of the office of the Superintendent of Documents. This position and the office were created by the passing of the Printing Act of 1895, which centralized the distribution and sale of government publications as well as the preparation of bibliographies that would index them. Her duties in Washington

were to care for the current documents after they had been recorded by the cataloguers and to collect all other documents. The Richardson Bill gave to the Superintendent of Documents the authority to remove to his custody from all the departments all the accumulations of documents not in use for the business of the departments. The removal of these accumulations fell to me. ${ }^{33}$

Two years after she arrived in Washington, John Shaw Billings, then director of the New York Public Library, visited the documents office, observed her efforts, and offered her a position in the Astor Library. She accepted the position and, in 1897, moved to New York. Hasse had tremendous respect for Billings, who had, in her estimation, an international perspective on the functions of a research library and the scope of its resources. She was given the opportunity to travel and acquire materials and was responsible, in 1902, for locating a copy of the supposedly lost 1695 Bradford Journal, which she later edited. ${ }^{34}$

After Billings' death in 1913, Hasse lost much of the momentum that had, with his support and interest, helped her to build an excellent documents collection and develop user-oriented services for businessmen. $\mathrm{He}$ had supported her in the compilation and publication of several significant bibliographies; her work in ALA also led to her preparation of a catalog handbook for documents. ${ }^{35}$

The new administrator of the library, E. H. Anderson, was not judged by Hasse to be a worthy successor to Billings. A disruptive and destructive personality conflict between Anderson and Hasse developed. She was not one to bear her troubles silently, and Anderson would not, could not allow her criticism to go unanswered. With the outbreak of World War I, matters grew even worse and rumors circulated throughout the staff about Hasse's pro-German sympathies. She perceived what she considered to be inferior work all around her; a catalog she had spent years developing was given to another department to manage; and, ultimately, she believed that she was purposely "ostracised from any activities of the library" ${ }^{36}$ including, in 1917, omission in the annual report of the librarian of reference to the work of her Economics Division, whose effective and resourceful services had become famous in the New York business community. By 1918, the entire matter had gone beyond reasonable reconciliation, and Hasse's resignation was requested. Never one to retreat, Hasse refused to leave quietly and requested a hearing before the executive committee. Her request was refused, and in October her employment was "terminated."

For anyone other than a personality of the strength and determination of Adelaide Hasse, the affair would have ended a professional life. Hasse, however, in addition to her own drive, had many colleagues who supported her regardless of their interpreta- 
tion of the incident. She returned to Washington, by request, and during the years from 1919 through the early 1940 s continued to organize records, prepare bibliographies, serve as a research consultant, and teach in the local universities. She officially stopped working in 1952 at the age of 83 , with her last major effort directed to the editing of state records for microfilm publication. ${ }^{37}$

\section{FLORA BELLE LUDINGTON (1898-1967)}

Although all the women profiled to this point had active careers in regional, state, and national associations, only Flora Ludington was able to scale the political ramparts that produce American Library Association presidencies. She was still a novice librarian when Sharp was dead, Mann an internationally known cataloger, Mudge an increasingly recognized authority on reference works, and Hasse a thirty-year veteran of special library services for the economics and business world.

Ludington came to the profession of librarianship when it was in the throes of serious criticism about its educational system, had yet to establish and clarify many of its standards, and had far more unanswered questions about users than it had answers or even the right questions. During her distinguished career, which was involved with two colleges-Mills and Mount Holyokeand international library development, Ludington never lost

sight of the first responsibility of the librarian-to bring together books and people, and she would add, "books that will inspire the mind, that will throw fresh lights on current problems ... books on a variety of subjects, not necessarily new books ... good books." Her reading as well as her writings encompass[ed] many diverse fields, and are worldwide in their extent. She [was] librarian, bookman, collector, and, perhaps, of greater importance, an informed and active citizen of the world. ${ }^{38}$

Flora Belle Ludington was born November 12, 1898, in Harbor Beach, Michigan, but while still a child, she moved with her family first to Idaho and later to Wenatchee, Washington. Her earliest association with library work came at the age of fourteen when she served as a volunteer in the local

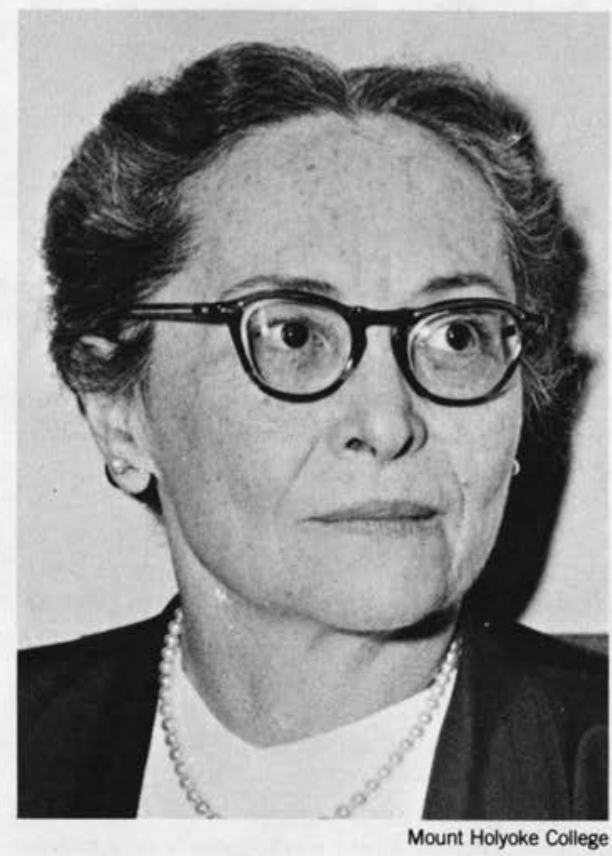

Flora Belle Ludington

Carnegie public library. That experience and her lifelong enchantment with the delights of reading and the joy of learning also involved her in work in the library of the University of Washington, Seattle, where she took her B.A. degree in librarianship, in 1920.

In her work in the library classes at Washington, she came under the strong guidance of William E. Henry. He was extremely supportive of the educational precept that "no one can teach efficiently who lacks enthusiasm for the subject taught, or who is deficient in human interests as distinguished from mere subject interest."39 The instructors at the library school were selected because Henry believed that their interest was the "welfare of the student." In addition, he espoused the then basic philosophy that the instructors should be practicing librarians. When this emphasis on the personal touch was combined with small classes and field work in the library, the stage for the Ludington career was well established. As one graduate and later professor of the school wrote, 
... every student went out with a call to service. ... As future librarians we became aware that we would have in our charge the recorded history of mankind. ... . we were responsible to see that books and information were diffused as widely as possible. There was nothing passive about librarianship and if we were to measure up to the demands of the profession, we must be up and doing. 40

"Up and doing" was soon to be a life-style for Flora Ludington. Upon completion of her bachelor's degree, she was employed to work as an assistant in the circulation department of the university but left to gain additional knowledge by studying for a year at the New York State Library School. That year, 1922, ended with her first significant appointment as reference librarian at Mills College, California.

Ludington remained at Mills for the next fourteen years. She was promoted first to assistant librarian, then added the role of assistant professor of bibliography, and, from 1935 to 1936 , was associate librarian. (In addition, she took the opportunity to earn a M.A. in history from the college; it was awarded in 1925, and, in that same year, she was granted the B.L.S. from the New York State Library School.)

The institutional memory at Mills College of her devotion, as well as her competence, was keen enough to bring the award of an honorary Doctor of Laws degree in 1953. The citation read: "Alumna of this college, and held in its affections; librarian who is a lover of learning as well as a custodian of books; leader in her profession at home and its honored representative abroad." 41

In 1936 Ludington was appointed librarian at Mount Holyoke, and she held this position until she retired in 1964. Although her primary responsibility remained in her work at Holyoke, she also carried on three other professional involvements: teaching, international library work, and association activities. From 1930 to 1943 she taught in the library schools, on one occasion or another, at the University of Texas, San Jose State, and Columbia University. Ludington's international library concerns were linked with her ALA work on the International Relations Board. During World War II, she was chairman of the Special Committee on International Cultural Relations and took a war leave from Mount Holyoke so that she could direct the U.S. information library in Bombay, India, from 1944 to 1946.

Miss Ludington served for several months in 1948 as visiting expert on information libraries in Japan for the Supreme Command for Allied Powers and was awarded the Certificate of Achievement of the Civil Information and Education Section. She [was] a member of the USIA's Advisory Committee on International Cultural Relations [from 1957 to 1964.] As chairman of a committee working with the ALA and the Ford Foundation to establish a library school at the University of Ankara in Turkey, she visited libraries there and in Lebanon in 1957. In 1959 she studied library development in Africa under a Rockefeller Foundation grant. ${ }^{42}$

Ludington was chosen as vice-president and president-elect of the American Library Association in 1952; she was president in 1953-54. Her election to that post came after years of service to a number of committees and boards. In her inaugural address she noted that

with the growth of libraries and consequent civilization, the bond which has kept the profession together is a firm conviction that books and the reading of them are important in a free society.... In an age of mass communication by means of the motion picture, radio and television the book may well offer a unique opportunity for one mind to meet another mind. ... The freer the society, the greater is the responsibility of the individual to be informed on the issues of the day. ${ }^{43}$

Her words were lucid reflections on a contemporary issue of monumental concern: it was the era of McCarthyism and intellectual freedom was under concerted attack. The Los Angeles conference during which she spoke endorsed the declaration "On Freedom to Read," which then and now enunciates the principle that the library "offers the opportunity to gain the information needed to understand diverging points of view on local, national and international affairs. . . . It imposes no thought control." 44

Not separate, but certainly distinctive in its own significance, is the administrative role Ludington played at Mount Holyoke. In the 1930s Mount Holyoke was in the midst of a major educational revision; it was apparent that the collection needed to be evaluated, and Ludington was quick to rec- 
ognize that a small college needed to cooperate with other institutions. Her emphasis on library cooperation was a major thrust of her life, and, when the Hampshire InterLibrary Center, Inc., was formalized in 1951, she would declare

no institution is an island sufficient unto itself, especially a library. It is rather a reservoir, continuously fed from many streams, but differing from other reservoirs in that the substance of which it is composed is not expended. ${ }^{45}$

Ludington's life, as well, was a "reservoir, continuously fed from many streams." She constantly sought to fill that reservoir for herself and for others through the libraries she fought to build and to save. At the height of the 1950s controversy, she wrote

... if libraries indoctrinate for anything it is for civilization, for liberty, for free press, for free religion, for free schools, for self government and democracy. Help the users of your libraries to preserve the inquiring mind whether it be how to make a better slip cover for a chair, or to overcome the sense of futility or belief that just one vote doesn't count, or to help those who are frightened or resistant to new ideas. Knowledge can be our greatest resource. ${ }^{46}$

Flora Belle Ludington retired as librarian of Mount Holyoke in 1964 after more than forty professional years of expert and influential contributions to twentieth-century libraries and librarianship.

\section{GENEVIEVE WALTON (1857-1932)}

In 1976 Cynthia Cummings, at the University of Wisconsin Library School, compiled and published "A BiographicalBibliographical Directory of Women Librarians." Five lines constitute the paragraph on Genevieve Walton; it is the briefest entry of the eighty-one women who are included.

Very little information could be found on Genevieve Walton. She appeared to be the librarian of Michigan State Normal College Library from 1892, and until at least 1930. She also helped found the Michigan Library Association, and served as its first woman president. ${ }^{47}$

In concluding a biographical series on six women who "spoke for themselves" with a sketch of Genevieve Walton, the beginning as well as the end of an unusual period of

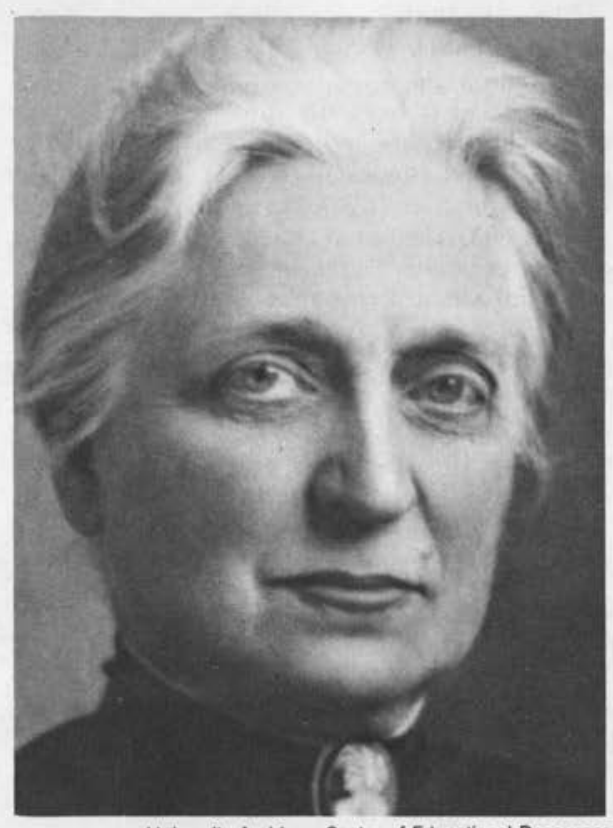

University Archives, Center of Educational Resources Eastern Michigan University

\section{Genevieve Walton}

library development is reflected. Unique women, as stated in the introductory paragraphs, have often been misplaced in the history of academic and research libraries. Despite their speaking and their doing, the result has been reduced to a minimum of record and a lost recognition.

So it was with Genevieve Walton, who spent forty years as "a distinguished librarian and book lover" 48 in a single position, librarian of Michigan's first "normal" school, now Eastern Michigan University, in Ypsilanti. Appointed as librarian in 1891, she continued to work in the library until a few months before her death in April 1932. The culmination of her dedication to that institution occurred in January 1930 when she was able to attend the formal opening of the new library building. Charles McKenny, president of the institution, wrote of her contribution, both to the institution and the library:

It has been the good fortune of the Michigan State Normal College to have as chief of staff in the library department a woman of unusual gifts 
as librarian. With personality, technical training, a grasp of the far reaches of her office and at the same time a gift for detail, Miss Genevieve M. Walton ... has been the directing spirit of the college library, has made a notable contribution to the life of the campus..... Miss Walton's hundreds of friends, on the faculty, among the citizens of Ypsilanti and among the alumni of the college, congratulate her on her years of unusual successful administration. ${ }^{49}$

It seems difficult to perceive that an individual, who was as knowledgeable and who had as much influence on library development in the state of Michigan as did Genevieve Walton, should have so little record outside of that state. As William Warner Bishop commented, "Her work, year after year, for the Michigan Library Association in planning and carrying through library institutes, has had results far beyond those which lie on the surface." 50 Since Michigan was noted early for its emphasis on libraries and often pioneered in areas of library innovation that have become standards for other states, Walton's commanding role at a turning point in its library history should not be overlooked.

Genevieve Walton was born June 25, 1857, in the city, Ypsilanti, in which she lived her entire life and died; her family is recognized as "one of the pioneer families of that city." 51 She attended St. Mary's Academy in South Bend, Indiana. Her major interest during those years was in the study of art, especially painting.

Walton's transition from a young girl interested in painting and the world of art to that of a dedicated "career" librarian is not recorded in great detail. As did Hasse, Mudge, and Sharp, she rejected the teaching profession per se and became involved in the emerging field of library work. Prior to Walton's appointment to the position of librarian at the normal school, there is no indication that she attended any special courses or worked in a library, although the role of "bookman" was clearly hers before the 1890s. However, in April 1891 William I. Fletcher, then librarian at Amherst College, offered

a brief course calculated to give beginners in library work or the librarians of small libraries who have not been brought in contact with modern improved methods, enough instruction in such methods to answer their immediate demands. ${ }^{52}$

This "brief course" became a five weeks' program taught by Fletcher himself; Genevieve Walton attended the Fletcher program and supplemented that background "through the meetings and journals of library associations and personal contacts with other librarians. Problems of book selection, classification and cataloging she met with what limited tools were available, adapting them to her own special situation." 53

This constituted her preparation; the dramatic results obviously built heavily on personal ability. Walton was thirty-four years old at the time of her appointment as librarian; she is judged to have initiated the "modern era" of the Michigan State Normal College library. Michigan State Normal College, founded in 1852, had grown considerably in the intervening years between its establishment and the Walton appointment. However, in 1892, the faculty still numbered only 31 , with a student enrollment of 1,002 ; there were 11,000 volumes in the library and Walton had one assistant who worked three hours a day. When the "new" library building was opened in 1930, it was a model facility, largely designed or influenced in its design by Walton.

The college had, in the thirty-eight years of Walton's tenure, expanded in many ways. By 1930, the enrollment had gone above 2,100 , the faculty numbered 200 , and there were 70,000 volumes in the library. Walton's staff had enlarged from one part-time helper to eleven staff members and fiftyeight student assistants. The library plan reflected that growth and Genevieve Walton's personal involvement.

As efficient as Walton was in the basic administration and development of the collection and the facilities, it is even more important to note her leadership in selecting a staff that would reflect her own ideas of service. President McKenny noted that skill when he commented that "it would be difficult to suggest in which way the staff could be improved. Alert, courteous and devoted are terms which could properly be applied to this group of workers which Miss Walton has brought together and inspired by her own sense of obligation." 54 That "obligation" was, in the final assessment, the 
truly outstanding factor that capsulizes her impact on the normal library and state library concerns.

Although Walton was not the prolific contributor to the library literature that can be seen in the writings of Hasse and Mudge, she did present a number of papers at both state and national conferences on topics related to the joy of reading and the "friendly book." She was invariably described, one colleague noted, as "a woman who can discuss books so that you can hardly wait to read the ones she talks about." 55 Her many friends claimed, as did Anne Carroll Moore, that their friendship was "rooted in love and admiration of good comradeship in books and good fellowship in human relations." 56

In the end, it is difficult to conclude. Prophetically, in 1925, Genevieve Walton gave a commencement address at the Pratt Library School; it was entitled "The Lost Librarian." 57 Although the speech dealt with book lovers and book loves, its title has a special knell when associated with an individual of whom it was said, "no one who has met Miss Walton ever forgot her." 58

The richness of her contributions to the library world once resounded in the phrases of those who knew of her work and those who knew her. "Her professional zeal, breadth of interest, concern for the training of teachers, positive character and personal charm"59 were common knowledge. Her "fidelity to high ideals, amid discouragements and delays," 60 the "intellect [that] demanded and deserved attention," 61 made her the woman who stood "head and shoulders above us." 62 That Genevieve Walton should become the "lost librarian" of the 1970 s reflects, once again, how little the profession knows and values its heritage.

\section{CONCLUSION}

There is no real conclusion to a series of biographical profiles of influential women librarians. Each one, in her own individuality, made special contributions to the field while all, together, represent only a small sample of those who might as logically have been included. Yet, Sharp's contribution to education for librarianship in the Midwest and her concern with collection, organization, and development at the University of Illinois can only be regarded as significant library factors at the turn of the century. In the case of Isadore Mudge, there are few who would challenge her place in the history of reference work, which suggests that what she did became a model for academic and research libraries and library schools. Margaret Mann justifiably emerges as one of the first practitioners of classification and cataloging, who made the teaching of that difficult field a matter of logic and method while preserving the creatively challenging role of the cataloger.

Controversial, dynamic, and innovative, Adelaide Hasse explored resources and advocated services that went beyond most contemporary perceptions, while Flora Ludington defended with magnificent strength and clarity the most valued ideal of the library world, the freedom to read.

Finally, a librarian who has been forgotten or never known, Genevieve Walton, could reach what the entire profession ultimately strives to achieve: "few that ever had any contact with her failed to benefit in some way by it." 63 These were six who "spoke for themselves."

\section{REFERENCES}

1. Robert B. Downs, "The Role of the Academic Librarian, 1876-1976," College \& Research Libraries 37:491-502 (Nov. 1976).

2. Edward G. Holley, "Librarians, 1876-1976," Library Trends 25:183 (July 1976).

3. Stanley McElderry, "Readers and Resources: Public Services in Academic and Research Libraries, 1876-1976," College \& Research Libraries 25:408 (Sept. 1976).

4. Wayne Stewart Yenawine, "The Influence of
Scholars on Research Library Development at the University of Illinois" (Doctoral dissertation, Univ. of Illinois, 1955), p.36.

5. Letter of Melvil Dewey to Francis Simpson, March 21, 1922 (Sharp Memorial Correspondence, Univ. of Illinois Archives).

6. Ibid.

7. McElderry, "Readers and Resources," p.409.

8. John Neal Waddell, "Mudge, Isadore Gilbert," in Encyclopedia of Library and Infor- 
mation Science (New York: Marcel Dekker, 1976), 18:287.

9. John Neal Waddell, "The Career of Isadore G. Mudge: A Chapter in the History of Reference Librarianship" (Doctoral dissertation, Columbia Univ., 1973), p.46.

10. Letter of Katharine Sharp to Lodilla Ambrose, April 17, 1901 (Sharp Papers, Letterbook 7, p.113, Univ. of Illinois Archives).

11. Univ. of Illinois, Library, Reference Department, Annual Report, 1902-03, p.16.

12. Isadore Mudge and Minnie E. Sears, A Thackeray Dictionary: The Characters and Scenes of the Novels and Short Stories Alphabetically Arranged (London: Routledge; New York: Dutton, 1910).

13. W. Dawson Johnston and Isadore G. Mudge, Special Collections in Libraries in the United States. U. S. Bureau of Education Bulletin, \#23 (Washington, D.C.: Govt. Print. Off., 1912).

14. Alice Bertha Kroeger, Guide to the Study and Use of Reference Books: A Manual for Librarians, Teachers and Students (Boston: American Library Assn., c1902).

15. Constance M. Winchell, "Preface," in Guide to Reference Books (7th ed.; Chicago: American Library Assn., 1951), p.v.

16. Isadore G. Mudge, "Reminiscences of Nicholas Murray Butler," in Columbia University, Oral History Collection, October 15, 1955 , quoted in John Neal Waddell, "The Career of Isadore G. Mudge," p.126.

17. Waddell, "Mudge, Isadore Gilbert," p.28889.

18. Winchell, "Preface," p.v.

19. William Warner Bishop, "Margaret Mann," Catalogers' and Classifiers' Yearbook (Chicago: American Library Assn., 1938), 7:14.

20. Margaret Mann, Introduction to Cataloging and the Classification of Books (Chicago: American Library Assn., 1930).

21. Donald James Lehnus, "Milestones in Cataloging, 1835-1969; An Attempt at an Objective Approach to the Growth of a Subject Literature" (Doctoral dissertation, Case Western-Reserve Univ., 1973), p.168.

22. Margaret Mann, "Specialized Cataloging in a One-Year Library School," Libraries 34:307 (July 1929).

23. Univ. of Illinois Library, Report of the Head Librarian, 1897/98, p.13.

24. Bishop, "Margaret Mann," p.11-12.

25. Margaret Mann, "What it Means to Catalog," Library Notes and News 8:288 (1927).

26. Margaret Mann, "Selective Cataloging in a Public Library," quoted in Dorothy R. Shaw, "The Life and Work of Margaret Mann" (Master's thesis, Drexel Institute of Technol- ogy, 1950), p.10.

27. "Famed for Her Library Knowledge," The San Francisco Call, July 9, 1897.

28. Phyllis Dain, The New York Public Library: A History of Its Founding and Early Years (New York: The New York Public Library, 1972), p.115.

29. Adelaide Rosalie Hasse, The Compensations of Librarianship (Privately printed, 1919), p.3.

30. Adelaide Rosalie Hasse, Index of Economic Material in Documents of the States of the United States, Prepared for the Department of Economics and Sociology of the Carnegie Institution of Washington (Washington, D.C.: Carnegie Institution of Washington, 190722), $22 \mathrm{v}$.

31. R. R. Bowker, "Women in the Library Profession," Library Journal 45:640 (Aug. 1920).

32. Adelaide Rosalie Hasse, List of Publications of the U.S. Department of Agriculture from 1841-1895, U.S. Dept. of Agriculture Library Bulletin No. 9 (Washington, D.C. Govt. Print. Off., 1896).

33. Hasse, The Compensations of Librarianship, p.5.

34. New York (Colony), General Assembly, 1695, House of Representatives, A Journal of the House of Representatives for His Majestie's Province of New York in America. Reproduced in facsimile from the first edition printed by William Bradford, 1695, with an introductory note by Adelaide R. Hasse (New York: Dodd, 1903).

35. Adelaide Rosalie Hasse, United States Government Publications, A Handbook for the Cataloger (Boston: Library Bureau, 1902-03).

36. Hasse, The Compensations of Librarianship, p.14.

37. William S. Jenkins, Collecting and Using the Records of the States of the United States; Twenty-five Years in Retrospection (Chapel Hill, N.C.: Bureau of Public Records, Univ. of North Carolina, 1961).

38. Margaret L. Johnson, "Flora Belle Ludington: A Biography and Bibliography," College \& Research Libraries 25:376 (Sept. 1964).

39. William E. Henry, quoted in John S. Richards, "University of Washington School of Librarianship: The First Fifty Years," Library News Bulletin 28:12 (July-Aug.-Sept. 1961).

40. Richards, "University of Washington School of Librarianship," p. 12.

41. Anne C. Edmonds, "Ludington, Flora Belle (1898-1967)," in Dictionary of American Library Biography (Littleton, Colo.: Libraries Unlimited, 1978), p.322.

42. Johnson, "Flora Belle Ludington," p.375. 
43. Flora B. Ludington, "Taproot, Trunk and Branches," A.L.A. Bulletin 47:371-72 (Sept. 1953).

44. Ibid.

45. Flora B. Ludington, "Hampshire InterLibrary Center," A.L.A. Bulletin 46:10 (Jan. 1952).

46. Flora B. Ludington, “Our Common Interests and Purposes," PNLA Quarterly 18:80 (Oct. 1953).

47. Cynthia S. Cummings, comp., “A Biographical-Bibliographical Directory of Women Librarians" (Madison: Library School Women's Group, Univ. of Wisconsin, 1976).

48. Anne Carroll Moore, "From Miss Moore," Michigan Library Bulletin 21:75 (March 1930).

49. Charles McKenny, "The Contribution of the Library to the Michigan State Normal College," Michigan Library Bulletin 21:66 (March 1930).

50. William Warner Bishop, "From Mr. Bishop," Michigan Library Bulletin 21:73 (March 1930).

51. "Miss Walton," Michigan Library Bulletin
23:98 (July 1932).

52. American Library Association, "Proceedings, 1891," Library Journal 16:88 (Dec. 1891).

53. Egbert R. Isbell, A History of Eastern Michigan University: 1849-1965 (Ypsilanti: Eastern Michigan Univ. Press, 1971), p.298.

54. McKenny, "The Contribution of the Library," p.66-67.

55. Elisabeth Knapp, "From Miss Knapp," Michigan Library Bulletin 21:77 (March 1930).

56. Moore, "From Miss Moore," p.75.

57. Genevieve Walton, The Lost Librarian (New York: 1925). Also sished in the NYPL Bulletin 29:529-39 (19: a).

58. Katharyne Sleneau, "From Miss Sleneau," Michigan Library Bulletin 21:82 (March 1930).

59. Isbell, A History of Eastern Michigan University, p.297-98.

60. Bishop, "From Mr. Bishop," p.73.

61. Knapp, "From Miss Knapp," p.77.

62. Agnes Jewell, "From Miss Jewell," Michigan Library Bulletin 21:81 (March 1930).

63. "Miss Walton," p.97.

\section{ABOUT COLLEGE \& RESEARCH LIBRARIES}

College $b$ Research Libraries (CひRL) is the official publication of the Association of College and Research Libraries, a division of the American Library Association. It is published seventeen times a year-six bimonthly journal issues and eleven monthly (combining July-August) news issues.

As the official publication of ACRL, College \& Research Libraries maintains a record of policy statements and actions taken by the association. In reporting activities of ACRL and its sections, it thus serves as the principal medium of communication among ACRL membership.

The publication is also a medium for professional communication among academic and research librarians. The journal issues contain reports of research and thoughtful articles on matters of current and continuing concern, communications from readers related to those articles, and reviews and announcements of important and relevant publications.

The news issues report activities and programs of the association, information and news related to academic and research libraries and their personnel, and brief notices of relevant publications.

General information on submission of manuscripts may be found on the masthead page in each issue. More detailed information on the journal and news issues is included in a statement in the April 1978 issue of College \& Research Libraries News, pages 86 and 87 . 